\title{
Protective Effect of Cleome Viscosa Extract on Diet Induced Atherosclerosis in Diabetic Rats Faheemuddin $M^{1^{*}}$, Janardhan $M^{1}$, Hassan $M^{2}$
}

\begin{abstract}
${ }^{1}$ Department of Pharmacology, Nimra College of Pharmacy, Jawaharlal Nehru Technical University Kakinada, Kakinada533003, Andhra Pradesh, India

${ }^{2}$ Department of Pharmacy Practice, Smt. Sarojini Ramulamma college of pharmacy, Palamur University, Mahbubnagar509001, Telangana, India
\end{abstract}

*Corresponding author: Faheemuddin M, Department of Pharmacology, Nimra College of Pharmacy, Jawaharlal Nehru Technical University Kakinada, Kakinada-533003, Andhra Pradesh, India, E-mail: faheemuddin.md4u@gmail.com

Received: February 05, 2017; Revised: February 26, 2017; Published: March 06, 2017

Copyright: (02017 Faheemuddin M, et al. This is an open-access article distributed under the terms of the Creative Commons Attribution License, which permits unrestricted use, distribution, and reproduction in any medium, provided the original author and source are credited. The article has been previewed and authenticated by the Authors before sending the publication for print. The Journal, Editor and the Editorial Board are not entitled or liable to either justify or responsible for inaccurate and misleading data if any. It is the sole responsibility of the Author concerned.

Citation: Faheemuddin M, Janardhan M, Hassan M. Protective Effect of Cleome viscosa Extract on Diet Induced Atherosclerosis in Diabetic Rats. Int J Pharm Pharmacol 2017; 1: 103.

\begin{abstract}
The atherosclerotic effect of Methanolic extract of Cleome viscosa was studied in Streptozotocin induced Diabetic Rats fed with Atherogenic Diet [1.5 ml olive oil containing $8 \mathrm{mg}$ of vitamin D-2 and $40 \mathrm{mg}$ cholesterol] for 5 consecutive days. Oral administration of extract to diabetic rats [250 $\mathrm{mg} / \mathrm{kg}$ and $500 \mathrm{mg} / \mathrm{kg}$ for 30 days] produced significant ( $p<0.01$ ) fall in fasting blood glucose levels in a dose dependent manner, when compared to standard drug that is Glibinclamide (5 mg/kg). Treatment with extract $250 \mathrm{mg} / \mathrm{kg}$ and $500 \mathrm{mg} / \mathrm{kg}$ showed significant $(P<0.01)$ improvement serum lipids levels that is total cholesterol, triglycerides(TG), low density lipoprotein $(L D L)$ and very low-density lipoprotein(VLDL), when compared to diabetic control. Histopathological studies of aorta also confirmed biochemical findings. Thus, our study shows that Methanolic extract of Cleome viscosa (250 $\mathrm{mg} / \mathrm{kg}$ and $500 \mathrm{mg} / \mathrm{kg}$ ) significantly improves the homeostasis of glucose and fat and possess anti atherosclerotic activity.
\end{abstract}

Keywords: Cleome viscosa, Methanolic extract, Atherosclerosis, diabetic rats, Glibinclamide, Streptozotocin, Vitamin D2.

\section{Introduction}

Diabetes mellitus is a group of metabolic disorders with one common manifestation hyperglycemia. Chronic hyperglycemia causes damage to eyes, kidneys, nerves, heart and blood vessels. It is caused by inherited and/or acquired deficiency in production of insulin by the pancreas, or by the ineffectiveness of the insulin produced. It results either from inadequate secretion of hormone insulin, an inadequate response of target cells to insulin, or a combination of these factors. This disease requires medical diagnosis, treatment and changes in life style. It is projected to become one of the world is main disablers and killers within the next 25 years [1]. 
Elucidation of the role of cholesterol in the pathogenesis of atherosclerosis is often referred to as one of the greatest till date discoveries. Some of the milestones on the road to acceptance of the 'lipid hypothesis' which proposed that hypercholesterolemia was a causative factor in human atherosclerosis. Atherosclerosis may be defined as degenerative changes in the intima of medium and large arteries. The degeneration includes accumulation of lipids, complex carbohydrates, blood and blood products, and cellular waste products, and is accompanied by the formation of fibrous tissues and calcium deposition in the intima of blood vessels [2].

Accelerated atherosclerosis occurs in animal models with engineered deficiencies in [apo (a)] or LDL receptors. Other genetic or acquired disorders (e.g., diabetes mellitus, hypothyroidism) that cause hypercholesterolemia lead to premature atherosclerosis. Lowering serum cholesterol by diet or drugs slows the rate of progression of atherosclerosis, causes regression of some plaques, and reduces the risk of cardiovascular events [3].

The management of diabetes is a global problem until now and successful treatment is not yet discovered. There are many synthetic medicines developed for patients, but it is the fact that it has never been reported that someone had recovered totally from diabetes. The modern oral hypoglycemic agents produce undesirable and side effects. Thus, alternative therapy is required, a need of hour is to shift towards the different indigenous plant and herbal formulations. The traditional medicines demonstrated a bright future in therapy of diabetes and to understand the importance of traditional herbs, in the present study the Cleome viscosa has reported to have nutritional, antioxidant and free radical scavenging properties in has been reported to possess anit oxidant, wound healing, analgesic, antidiarrheal, antipyretic, anti-emetic, antimicrobial and diabetic hepato-protective and diabetic neuroprotective $[4,5]$.

\section{Materials and Method}

\section{Materials}

Faheemuddin M, et al. Int J Pharm Pharmacol
All chemicals were of analytical grade and obtained locally. Cholesterol, Triglycerides and HDL-C kit were procured from Robonik diagnostics, Hyderabad, India.

\section{Plant Material}

The fresh plant Cleome viscosa was collected from Mahabubnagar, A.P. Identification of the plant was done by Dr. K. Madhava Chetty Assistant Professor, Department of Botany, Sri Venkateswara University, Tirupati, A.P, India.

\section{Animals}

Wister albino adult male rats weighing 200-220 $\mathrm{g}$ were selected and housed in polypropylene cages in a room where the congenial temperature was $27^{\circ} \mathrm{C} \pm 1^{\circ} \mathrm{C}$ and $12 \mathrm{~h}$ light and dark cycles were maintained. The animals were allowed to acclimatize to the environment for 7 days and supplied with a standard pellet diet and water ad libitum. The composition of atherogenic diet used during the study was as given. Each of these treatment groups consisted of six animals/group. The protocol of this study was approved by the Institutional Animal Ethics Committee (IAEC) constituted under Committee for Purpose of Control and Supervision of Experiments on Animals (Reg No: 769/2010/CPCSEA) [6].

\section{Method}

\section{Preparation of the Extract}

The whole plant was isolated, chopped into small pieces and dried under shade at room temperature for seven days. The dried plant was powdered and passed through the sieve (coarse 10/44). This powder was used for the preparation of Methanolic extract.

\section{Methanolic Extract}

Methanolic extract was prepared by Heat Soxhlet extractor. The dried coarse powdered of plant $(250 \mathrm{gm})$ were transferred to a round bottom flask, $99 \%$ of Methanol was added to the flask and soaked for $2 \mathrm{~h}$. This was then boiled for $4 \mathrm{~h}$. The extract obtained was decanted in a beaker and then concentrated to $1 / 6^{\text {th }}$ of the total volume on a water bath. This was preserved by adding a few drops of chloroform and kept in the refrigerator. This 
extract was administered to the animals by making the concentration required by weighing the water-evaporated extract $(24.5 \%$ yield $)$. The extract was assigned a code name MECV.

\section{Induction of Diabetes}

A freshly prepared solution of streptozotocin (45 mg/kg in $0.1 \mathrm{M}$ buffer citrate solution) is injected to overnight fasted rats. After $48 \mathrm{hrs}$ the rat's blood glucose levels of $250 \mathrm{mg} / \mathrm{dl}$ or above were considered for the further study [7].

\section{Induction of Atherosclerosis}

Although the cause and pathogenesis of atherosclerosis remains largely unresolved, it is generally agreed that correlation exists between high blood cholesterol and cardiovascular diseases. Atherogenic Diet for the first time succeeded in inducing atherosclerosis in rabbits by feeding cholesterol containing diet. Development of atherosclerosis in rabbits usually takes at least 60 days of feeding atherogenic diet. Rat is said to be resistant to such dietary manipulations for the development of atherosclerosis, but with supplementation of very high doses of vitamin D-2 along with Atherogenic diet, success has been achieved in developing atherosclerosis in rats in a short period. The atherogenic diet (AD) consisting of $1.5 \mathrm{ml}$ olive oil containing $8 \mathrm{mg}(3,20,000 \mathrm{IU})$ vitamin D2 and $40 \mathrm{mg}$ cholesterol and was given for 5 consecutive days (Table 1). The rats were fed with high fat diet along with weekly challenge of oral vitamin D-2 for one month through oral route $[6,7]$.

\section{Toxicological Studies}

The Methanolic extract of plant is subjected to toxicological studies and the rats were observed for every $4 \mathrm{~h}$ till for $24 \mathrm{~h}$ for 30 days and behavioural changes and mortality were observed, it was found to be safe. The low dose of $250 \mathrm{mg}$ and high dose of $500 \mathrm{mg} / \mathrm{kg}$ body weight of rat is being selected for the study.

\section{Experimental Protocol}

In order to induce atherosclerosis, the method reported by Sharma et al. [7] and Tanwar et al. [6] was followed. The animals were divided into five groups of six rats each and they received the following diets with or without treatment for 30 days orally:

Group I: Normal diet

Group II: Atherogenic diet + STZ (45 mg/kg)

Group III: Atherogenic diet + STZ (45 mg/kg) + Glibinclamide $(5 \mathrm{mg} / \mathrm{kg} /$ day $)$

Group IV: Atherogenic diet + STZ (45 mg/kg) $+\operatorname{MECV}(250 \mathrm{mg} / \mathrm{kg} /$ day $)$.

Group V: Atherogenic diet + STZ (45 mg/kg) + MECV (500 mg/kg/days).

At the end of the treatment the rats were fasted overnight, blood was drawn from retro orbital plexus as per CPCSEA guidelines. Serum was separated and stored in refrigerator until assay

\section{Measurement of Various Parameters}

\section{Physical Parameters}

The body weight was recorded on the first day and then last day of the study period in each group.

\section{Blood Glucose Levels}

The glucose levels were determined by using commercial glucometer kit on initial and final day of the experiment by collecting blood from rat's tail.

\section{Biochemical Estimations}

Lipid parameters were determined in blood serum, at the initial day and on final day of 30 days, animals were fasted overnight and blood was collected from retro orbital plexus under light ether anaesthesia, centrifuged at $2500 \mathrm{rpm}$ for 20 minutes. The serum obtained will be kept at $4^{\circ} \mathrm{C}$ until used.

The quantitative estimation of lipid profile was carried out using Infinite triglycerides liquid for triglycerides, Infinite cholesterol liquid for total cholesterol and Autozyme for HDL-C, ACCUREX in SICRA laboratory. Estimation of VLDL-C and LDL-C was done by using the Friedward's formula

VLDL-C=Triglycerides $/ 5$ 
LDL-C=Total cholesterol-(HDL-C+VLDL-C).

\section{Histopathology of Aorta}

For histopathology, the rats were sacrificed by cervical decapitation and their aortas were dissected out. During the procedure, ice was used to keep the aorta samples fresh and avoid any degradation. The aortas were stored in 10\% formaline solution and sent to a local pathological laboratory for hematoxyline and eosine staining [6].

\section{Statistical Analysis}

The results are expressed as mean \pm standard error of mean (SEM). The data were analyzed using one-way analysis of variance (one-way ANOVA) followed by Dunnett multiple comparison test for comparison between groups. The criterion for statistical significance was $\mathrm{p}<0.05$.

\section{Results}

\section{Atherogenic Diet (AD) Induced Atherosclerosis in Diabetic Rats}

The Methanolic extract of the Cleome viscose has shown significant effect on the serum lipid profile and blood glucose levels. Whereas it hasn't show a significant effect on controlling the body weight. The blood glucose levels were initially high with no significant effect till $6^{\text {th }}$ day of the study but gradually from the $15^{\text {th }}$ day the decrease in the blood glucose levels was observed which on the final day shown the highly significant decrease in the elevated blood glucose levels at high dose of the plant extract and standard drug treatment.

The serum lipid profile was checked at initial and final day of the study, the high dose and standard drug treatment has shown the significant effect of the plant extract.

Effect of administration of Methanolic extract of Cleome viscosa (250 and 500 $\mathrm{mg} / \mathrm{kg}$ P.O once daily for 30days)/ Glibinclamide $(5 \mathrm{mg} / \mathrm{kg} / \mathrm{P} . O$ once daily for 30 days) on Histopathological changes in aorta of rats fed with $\mathrm{AD}$ for 30 days.

\section{Group 1}

The thoracic aorta of animal from group 1 showed normal histological features of the tunica layers. The tunica intima was composed of a continuous layer of endothelial cells. The tunica media appeared to have normal \& healthy numerous distinct elastic laminae, which were wavy \& arranged concentrically, with smooth muscle cells seen in the interspaces between the concentric lamellae. There was no significant increase in the media thickness. The tunica adventitia was recognized by the normal-looking fibrous tissue elements (Figure 1).

\section{Group 2}

In group 2 there was vascular wall thickening resulting from an increase in the thickness of tunica media observed as smooth muscle hyperplasia among regular concentric elastic laminae, on the expense of a relatively thin tunica adventitia (Figure 2).

\section{Group 3}

In group 3 the increase in the tunica media was less pronounced but the hyperplasia was irregular \& was associated with disruption of the concentric pattern of the elastic laminae regular luminal layers of endothelial cells were observed \& the internal elastic laminae showed areas of continuity (Figure 3 ).

\section{Group 4}

In group 4, few fibrocytes were spotted in the subendothelial regions. Fibrous elements of the tunica adventitia were also thickened in both groups as compared to the controls (Figure 4).

\section{Group 5}

Transverse section through the thoracic aorta of rats treated with MECV $(500 \mathrm{mg} / \mathrm{kg})$ showing subendothelial fibrocytes (short white arrows) \& intimal continuity (long black arrow X600) (Figure 5).

\section{Discussion}

High fatty diet is a very common cause of heart disease. Particularly, with an increase in tendency towards fast foods, which are rich in saturated fats, an increase in coronary heart 
disorder (CHD) in diabetic patients and normal patients is being observed in the developing countries since past few decades. A one percent decrease in HDL-cholesterol is associated with a 3-4\% increase in the risk of heart disease. In the present study, an increase in plasma HDLcholesterol with a concomitant percentage decrease in glucose and other lipid parameters were observed (Table 2 and Table 3). Treatment with extract of Cleome viscosa produced a significant decrease in the serum level of lipids and glucose in atherogenic diet induced atherosclerosis in Diabetic rats. Hence by considering the effects observed in this model, the possible mechanism of Cleome viscosa may involve increase of HDLcholesterol, which is attributed to the mobilization of cholesterol from peripheral cells to the liver by the action of Lecithin Cholesterol O-acyltransferase (LCAT) enzyme [8]. LCAT enzyme is involved in the transesterification of cholesterol, the maturation of HDL and the flux of cholesterol from cell membranes into HDL [3].

It can be concluded from the present data that the levels of total serum cholesterol, triglyceride and total protein which are raised in atherogenic diet, can be lowered significantly with extract of Cleome viscosa.

\section{Conclusion}

Thus, from the above results we can conclude that Cleome viscosa has anti-atherosclerotic activities in diet induced atherosclerosis in a STZ induced diabetic rats. Further study is required for the detailed elucidation of mechanism for the activity shown.

\section{Acknowledgement}

Authors are grateful to Dr. M Janardhan, head of the department, Nimra College of pharmacy.

\section{References}

1. Malviya N, Jain S, Malviya S. Review on Antidiabetic Potential of Medicinal Plants. Acta Pol Pharm 2010; 67: 113-118.

2. Aronson D, Rayfield EJ. How hyperglycemia promotes atherosclerosis: molecular mechanisms. Cardiovasc Diabetol 2002; 1: 1-10.

3. Kusunoki J, Aragane K, Kitamine T, et al. Postprandial Hyperlipidemia in Streptozotocin-Induced Diabetic Rats is Due to Abnormal Increase in Intestinal Acyl Coenzyme A: Cholesterol Acyltransferase Activity. Arterioscler Thromb Vasc Biol 2000; 20: 171-178.

4. Joshi T, Kumar N, Kothiyal P. A Review on Cleome viscosa: An endogenous Herb of Uttarakhand. Int J Pharm Res Rev 2015; 4: 25-31.

5. Mali RG. Cleome viscosa (wild mustard): A review on ethnobotany, phytochemistry, and pharmacology. Pharm Biol 2010; 48: 105-112.

6. Tanwar RS, Sharma SB, Singh UR. Antiatherosclerotic Potential of Active Principle Isolated from Eugenia jambolanain Streptozotocin - Induced Diabetic Rats. Evid-Based Compl Alt 2011; $9 \mathrm{p}$.

7. Sharma SB, Tanwar RS, Rini AC. Protective effect of Morus rubra L. leaf extract on diet-induced atherosclerosis in diabetic rats. Indian $\mathrm{J}$ Biochem Biophys 2010; 47: 26-31.

8. Srinivas M, Annapurna A, Narsimha Reddy Y. Anti-atherosclerotic effect of atorvastatin and clopidogrel alone and in combination in rats, Indian $\mathrm{J}$ Exp Biol 2008; 46: 698-703. 
Table 1: Atherosclerotic diet

\begin{tabular}{|l|c|}
\hline \multicolumn{1}{|c|}{ Ingredients } & Weight in grams \\
\hline Olive oil & $1.5 \mathrm{ml}$ \\
\hline Cholesterol & $40 \mathrm{mg}$ \\
\hline Standard pellet powder (Q.S) & 100 \\
\hline
\end{tabular}

Table 2: Effect of 99.9\% MECV on Body weight and Lipid profile on Atherosclerosis in STZ induced diabetic rats

\begin{tabular}{|c|c|c|c|c|c|}
\hline Group & Normal & Control & Standard & $\begin{array}{c}\text { MECV } \\
\text { T1 }\end{array}$ & $\begin{array}{c}\text { MECV } \\
\text { T2 }\end{array}$ \\
\hline $\begin{array}{l}\text { Initial } \\
\text { body } \\
\text { weight }\end{array}$ & $\begin{array}{l}166.7 \pm \\
1.89\end{array}$ & $\begin{array}{l}168.3 \pm \\
1.52\end{array}$ & $\begin{array}{l}173.7 \pm \\
1.82\end{array}$ & $\begin{array}{l}178.0 \pm \\
2.30\end{array}$ & $\begin{array}{l}177.2 \pm \\
2.71\end{array}$ \\
\hline $\begin{array}{l}\text { Final body } \\
\text { weight }\end{array}$ & $\begin{array}{l}202.0 \pm \\
3.10\end{array}$ & $\begin{array}{l}266.5 \pm \\
1.54\end{array}$ & $\begin{array}{l}219.2 \pm \\
3.51^{*}\end{array}$ & $\begin{array}{l}231.5 \pm \\
5.50\end{array}$ & $\begin{array}{l}225.2 \pm \\
3.28^{*}\end{array}$ \\
\hline $\begin{array}{l}\text { Initial } \\
\text { HDL }\end{array}$ & $\begin{array}{l}39.67 \pm \\
1.05\end{array}$ & $\begin{array}{l}23.00 \pm \\
0.85\end{array}$ & $\begin{array}{l}22.83 \pm \\
0.98\end{array}$ & $\begin{array}{l}22.67 \pm \\
0.71\end{array}$ & $\begin{array}{l}23.17 \pm \\
0.60\end{array}$ \\
\hline Final HDL & $\begin{array}{l}45.67 \pm \\
1.22\end{array}$ & $\begin{array}{l}13.83 \pm \\
0.60^{\mathrm{a}}\end{array}$ & $\begin{array}{l}32.17 \pm \\
0.94^{* *}\end{array}$ & $\begin{array}{l}30.33 \pm \\
0.88^{*}\end{array}$ & $\begin{array}{l}35.67 \pm \\
0.66^{* *}\end{array}$ \\
\hline $\begin{array}{l}\text { Initial } \\
\text { LDL }\end{array}$ & $\begin{array}{l}18.80 \pm \\
1.15\end{array}$ & $\begin{array}{l}61.67 \pm \\
2.08\end{array}$ & $\begin{array}{l}66.73 \pm \\
1.19\end{array}$ & $\begin{array}{l}65.33 \pm \\
1.40\end{array}$ & $\begin{array}{l}67.33 \pm \\
1.30\end{array}$ \\
\hline Final LDL & $\begin{array}{l}17.07 \pm \\
1.40\end{array}$ & $\begin{array}{l}102.3 \pm \\
2.75^{\mathrm{a}}\end{array}$ & $\begin{array}{l}35.50 \pm \\
1.67^{\text {*** }}\end{array}$ & $\begin{array}{l}62.80 \pm \\
2.28^{*}\end{array}$ & $\begin{array}{l}42.82 \pm \\
2.28^{* * * *}\end{array}$ \\
\hline $\begin{array}{l}\text { Initial } \\
\text { VLDL }\end{array}$ & $\begin{array}{l}14.87 \pm \\
0.22\end{array}$ & $\begin{array}{l}22.67 \pm \\
0.38^{c}\end{array}$ & $\begin{array}{l}22.10 \pm \\
0.28\end{array}$ & $\begin{array}{l}22.33 \pm \\
0.30\end{array}$ & $\begin{array}{l}22.17 \pm \\
0.36\end{array}$ \\
\hline $\begin{array}{l}\text { Final } \\
\text { VLDL }\end{array}$ & $\begin{array}{l}15.27 \pm \\
0.16\end{array}$ & $\begin{array}{l}31.40 \pm \\
0.69^{c}\end{array}$ & $\begin{array}{l}16.17 \pm \\
0.14^{* *}\end{array}$ & $\begin{array}{l}18.70 \pm \\
0.35^{*}\end{array}$ & $\begin{array}{l}15.60 \pm \\
0.31^{* *}\end{array}$ \\
\hline Initial TC & $\begin{array}{l}73.50 \pm \\
1.33\end{array}$ & $\begin{array}{l}108.2 \pm \\
2.18^{b}\end{array}$ & $\begin{array}{l}111.7 \pm \\
1.28\end{array}$ & $\begin{array}{l}110.3 \pm \\
1.54\end{array}$ & $\begin{array}{l}112.2 \pm \\
1.90\end{array}$ \\
\hline Final TC & $\begin{array}{l}78.00 \pm \\
1.23\end{array}$ & $\begin{array}{l}147.5 \pm \\
2.43^{\mathrm{a}}\end{array}$ & $\begin{array}{l}84.67 \pm \\
1.72^{* *}\end{array}$ & $\begin{array}{l}91.83 \pm \\
2.10^{*}\end{array}$ & $\begin{array}{l}77.33 \pm \\
1.45^{* *}\end{array}$ \\
\hline $\begin{array}{l}\text { Initial } \\
\text { triglycerid } \\
\text { es }\end{array}$ & $\begin{array}{l}74.33 \pm \\
1.11\end{array}$ & $\begin{array}{l}113.3 \pm \\
1.94^{b}\end{array}$ & $\begin{array}{l}110.5 \pm \\
1.43\end{array}$ & $\begin{array}{l}111.7 \pm \\
1.52\end{array}$ & $\begin{array}{l}110.8 \pm \\
1.83\end{array}$ \\
\hline $\begin{array}{l}\text { Final } \\
\text { triglycerid } \\
\text { es }\end{array}$ & $\begin{array}{l}76.33 \pm \\
0.80\end{array}$ & $\begin{array}{l}157.0 \pm \\
3.48^{\mathrm{a}}\end{array}$ & $\begin{array}{l}80.50 \pm \\
0.76^{* *}\end{array}$ & $\begin{array}{l}93.50 \pm \\
1.76^{*}\end{array}$ & $\begin{array}{l}78.00 \pm \\
1.57^{* *}\end{array}$ \\
\hline
\end{tabular}

$n s=$ not significant, one way analysis of variance (ANOVA) followed by Dunnett multiple comparison. ${ }^{* * *} P<0.001$

${ }^{* *} P<0.01$ and ${ }^{*} P<0.005$ as compared to control group. ${ }^{a} P<0.001{ }^{b} P<0.05$ and ${ }^{c} P<0.1$ as compared to normal group. 
Table 3: Effect of 99.9\% MECV extract on Fasting Blood Glucose levels on in STZ induced diabetic rats

\begin{tabular}{|l|l|l|l|l|}
\hline \multicolumn{1}{|c|}{ Group } & \multicolumn{1}{|c|}{$\mathbf{0}^{\text {th }}$ day } & \multicolumn{1}{|c|}{$\mathbf{6}^{\text {th }}$ day } & \multicolumn{1}{|c|}{$\mathbf{3 0}^{\text {th }}$ day } \\
\hline Normal & $82.67 \pm 1.05$ & $80.83 \pm 1.47$ & $82.67 \pm 1.54$ & $83.00 \pm 1.26$ \\
\hline Control & $313 \pm 1.47$ & $307.3 \pm 1.99$ & $326.7 \pm 2.65^{\text {a }}$ & $330.8 \pm 2.22^{\text {a }}$ \\
\hline Standard & $277.2 \pm 0.94$ & $309.5 \pm 0.76$ & $190.3 \pm 1.89^{* *}$ & $141.3 \quad \pm$ \\
& & & & $2.31^{* * *}$ \\
\hline MECV T1 & $297.0 \pm 0.57$ & $311.7 \pm 1.05$ & $223.3 \pm 1.54^{*}$ & $169.8 \quad \pm$ \\
& & & & $1.30^{* *}$ \\
\hline MECV T2 & $283.3 \pm 2.33$ & $314.8 \pm 1.57$ & $192.2 \pm 1.92^{* *}$ & $133.2 \quad \pm$ \\
& & & & $1.77^{* * *}$ \\
\hline
\end{tabular}

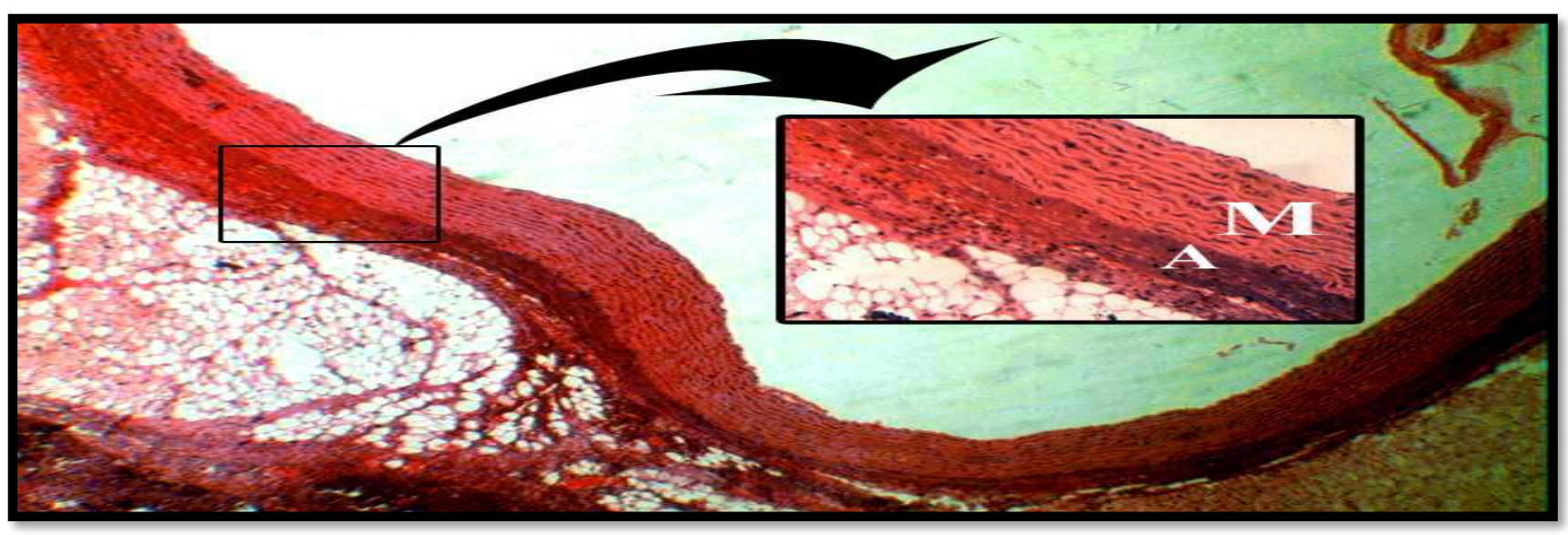

Figure 1: Histopathology of Aorta of group-I

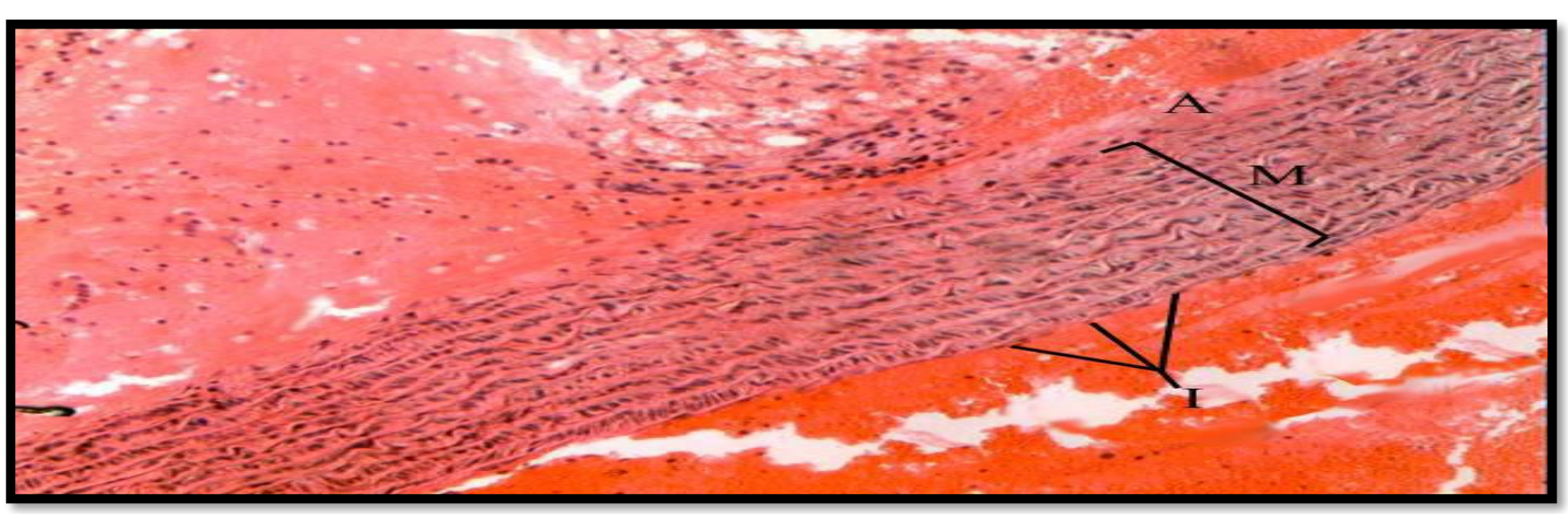

Figure 2: Histopathology of Aorta of group-II 


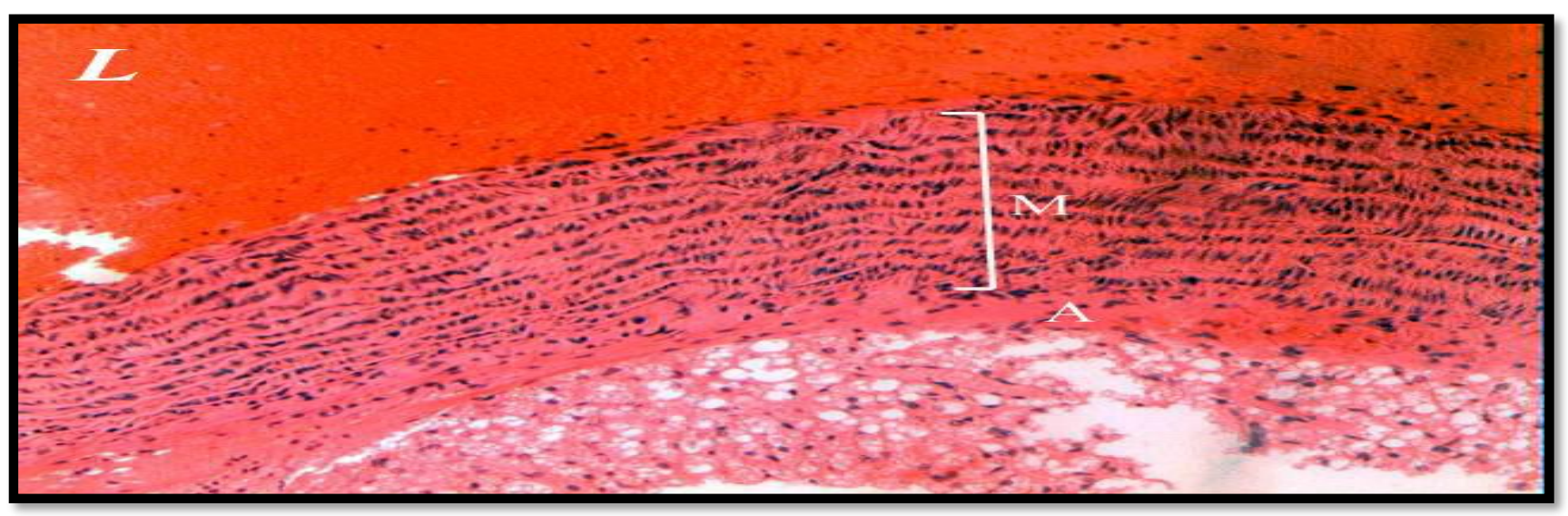

Figure 3: Histopathology of Aorta of group-III

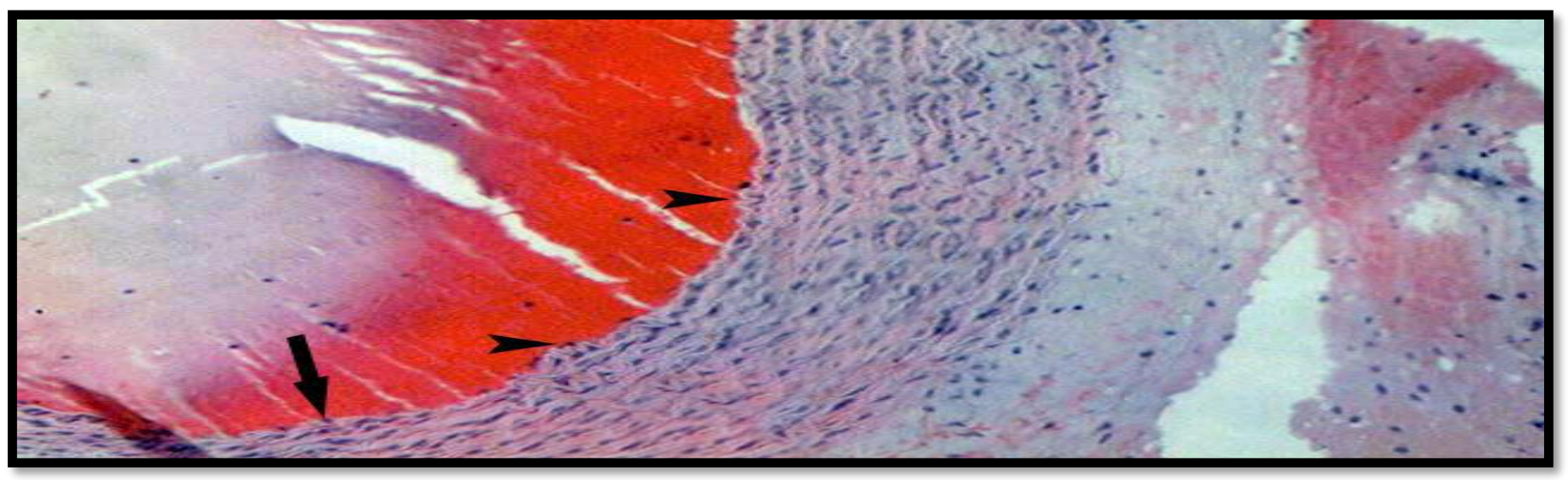

Figure 4: Histopathology of Aorta of group-IV

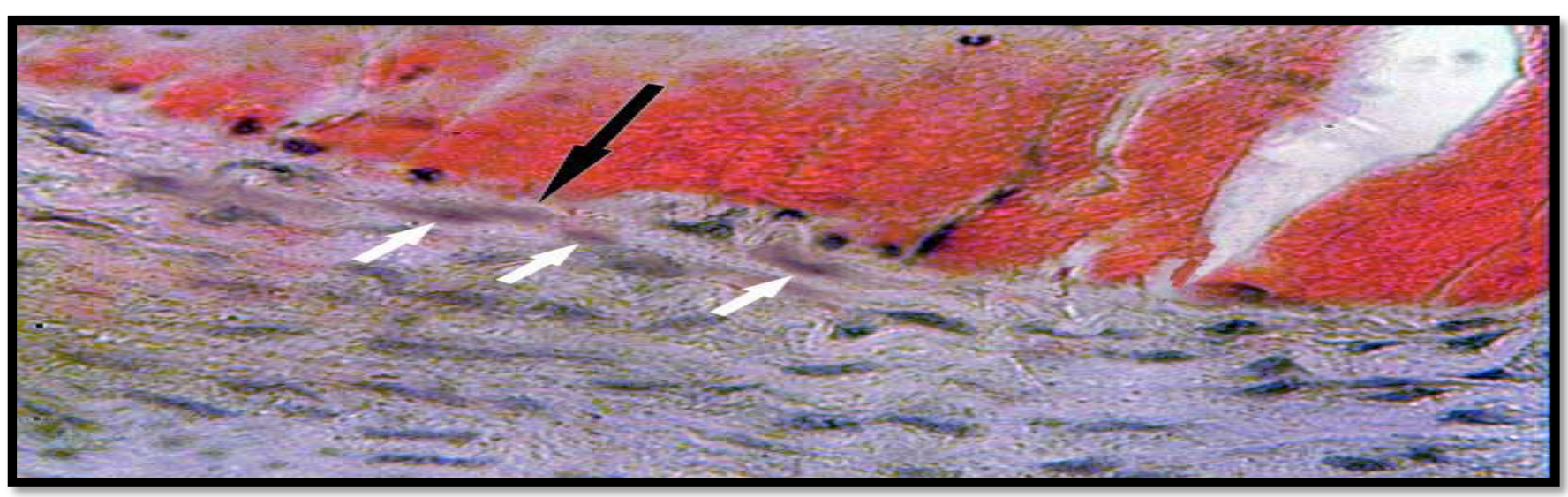

Figure 5: Histopathology of Aorta of group-V 
This manuscript was peer-reviewed

Mode of Review: Single-blinded

\section{Editor: Dr. Fatma Ibrahim Ali}

International Journal of Pharmaceutics and Pharmacology is an open access, peer reviewed journal published by Edwiser International.

Submit your valuable manuscript at-

editor.ijpp@edwiserinternational.com

submit.manuscript@edwiserinternational.com

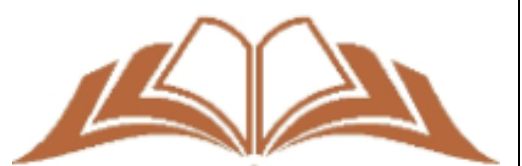

EDW $\mathrm{W}$ S E R
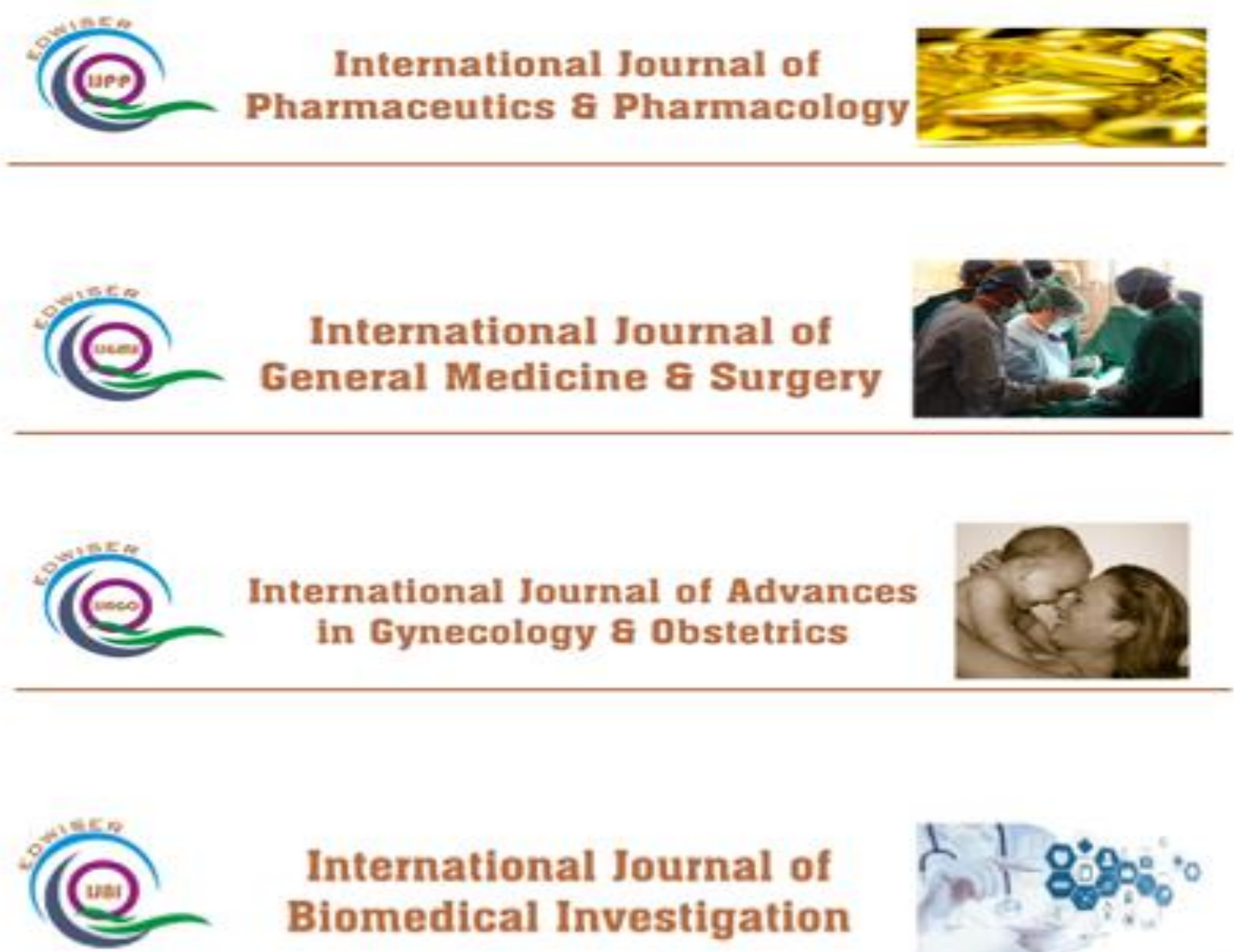

\section{International Journal of Biomedical Investigation}
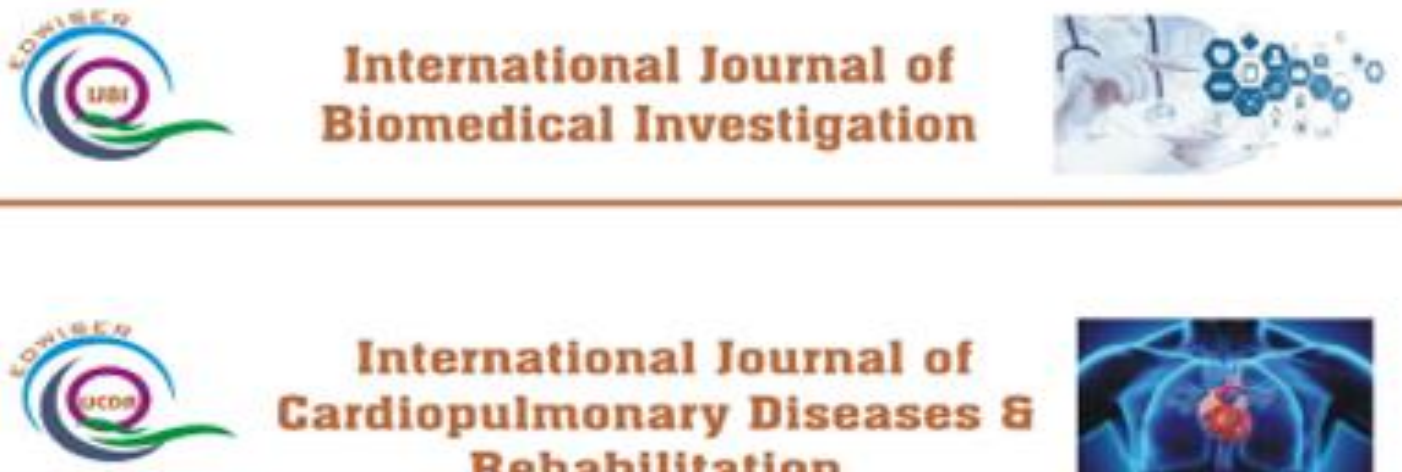

International Journal of Cardiopulmonary Diseases \& Rehabilitation

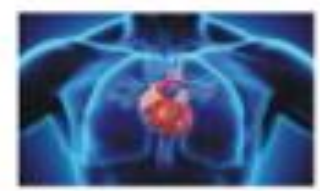

